\title{
Denis Sdvižkov, Epoka inteligencji. Historia porównawcza warstwy wykształconej w Europie, przekład J. Górny, red. A. Kożuchowski, Wydawnictwo Neriton, Warszawa 2011, ss. 311
}

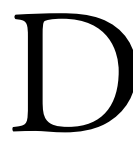

o Epoki inteligencji Denisa Sdvižkova należy się odnieść z atencją co najmniej z tego powodu, że podejmowanie badań komparatystycznych przez humanistów należy zawsze do zadań odpowiedzialnych. Książka ta zasługuje na uwagę tym bardziej, że jej Autor postanowił dokonać porównania - w moim przekonaniu - zagadnienia trudno porównywalnego, a mianowicie kształtowania się i rozwoju inteligencji w poszczególnych państwach europejskich. Zresztą już na wstępie należy zaznaczyć, że nie zawsze możemy mówić nawet o wyborze państw, bowiem Autor zdecydował się również na analizę rozwoju polskiej warstwy wykształconej, a jego rozważania skupiają się przecież głównie na XIX stuleciu. Z kolei wybór czterech krajów (Francja, Niemcy, Polska, Rosja) może wskazywać na to, że nazwy kontynentu w tytule książki użyto nieco wygórowanie (można wszakże upomnieć się chociażby o przypadki angielski i włoski). W moim przekonaniu trzeba docenić wysiłek Autora, który postanowił prześledzić rozwój wybranej grupy społecznej od Paryża do Moskwy, zwłaszcza że owocem prac jest bardzo udana książka.

W 2011 roku ukazało się polskie tłumaczenie Epoki inteligencji. Książka Denisa Sdvižkova, obecnie pracownika Niemieckiego Instytutu Historycznego w Moskwie, oparta została w pełni na literaturze wydanej do 2006 roku (wtedy bowiem ukazało się oryginalne wydanie pracy w języku niemieckim: Das Zeitalter der Intelligenz. Zur vergleichenden Geschichte der Gebildeten in Europa bis zum Ersten Weltkrieg, Göttingen 2006), co podkreśla sam Autor (s. 12). Jest to oczywiście zrozumiałe, wynika bowiem z ambitnego, komparatystycznego ujęcia wybranej problematyki.

Praca składa się (poza Wprowadzeniem Autora i Wstęem redakcyjnym Adama Kożuchowskiego) z pięciu zasadniczych rozdziałów, przy czym ostatni z nich pełni funkcję podsumowania. We Wprowadzeniu Autor odnosi się do znaczenia terminu „inteligencja” w sensie społeczno-historycznym, określa również ramy chronologiczne pracy. Książka dotyczy przede wszystkim zjawiska inteligencji jako warstwy społecznej ukształtowanej w XIX wieku, za datę końcową swych rozważań Sdvižkov przyjmuje 1914 rok (s. 13-25). Już w tym miejscu możemy zaznaczyć odnośnie ram chronologicznych, że w poszczególnych rozdziałach, dokonując charakterystyki powstania i rozwoju inteligencji w poszczególnych krajach europejskich w XIX wieku, Sdvižkov wykracza zarówno przed, jak i poza ramy XIX stulecia, co należy uznać za zaletę wykładu, pełniej przez to ukazującego omawianą problema- 
tykę. We Wprowadzeniu formułuje ponadto cel książki: „Ma ona w zwięzłej formie przekazać czytelnikom całościowy obraz historii inteligencji oraz przeanalizować najważniejsze zagadnienia związane z tym zjawiskiem” (s. 25).

Pierwszy z zasadniczych rozdziałów pracy poświęcony został warstwie wykształconej we Francji. W tej części, zatytułowanej Arbiter intelligentiarum - Intelektualiści francuscy - uniwersalny wzorzec czy ślepa ścieżka ewolucji? Autor przedstawia rodowód francuskiej inteligencji, odwołując się z początku do oświeceniowych tradycji intelektualnych i redefinicji inteligencji dokonanej w wyniku rewolucji francuskiej. Dalej stwierdza, że „właściwa historia francuskich intellectuels” powstała w okresie afery Dreyffusa (a dalej nawet, na s. 73, podaje konkretną datę - 1898 rok), kiedy owym pojęciem zaczęły się autodefiniować „awangardowe kręgi literackie i artystyczne" (s. 65-66). W rozdziale tym, podobnie jak w trzech kolejnych, Autor w bardzo interesujący sposób ukazuje dynamikę zmian życia i obyczajów mieszczańskiego kręgu intelektualistów, ewolucję ich systemu wartości, stosunku do pieniądza itd.

Kolejny rozdział nosi tytuł Odczarowany świat Czarodziejskiej góry. Niemiecka warstwa wyksztatcona między humanizmem a polityka. W części tej Autor dowodzi, że Prusy (bo na tym państwie niemieckim koncentruje swoją uwagę) w XIX wieku wybrały własną drogę, zdeterminowaną polityką państwa pruskiego i doświadczeniami historycznymi. Sdvižkov zwraca uwagę na znaczący udział duchownych protestanckich w rozwoju niemieckiej inteligencji. Wykształcenie zaczęło odgrywać coraz większą rolę w drodze awansu od końca XVIII wieku i odchodzenia od stanowego modelu społecznego. W XIX wieku pruskie idee oświatowe, którym w wyniku traumy po wydarzeniach lat 1806/1807 nadano istotny element narodowy i państwowy, zdominował neohumanizm. Sdvižkov podkreśla jego udział w rozwoju niemieckiego Bildungsbürgertum. Państwo, przyznając wykształceniu wysoką rangę w życiu społecznym i opierając swą politykę na klasycznym gimnazjum i autonomicznym uniwersytecie, odgrywało kluczową rolę w dalszych dziejach inteligencji, a przy tym intelektualiści określani mianem „liberalnych” odnosili kolejne porażki w ciągu XIX wieku. „Lojalna” warstwa wykształcona rozwijała się szczególnie w okresie cesarskim, co przejawiało się chociażby w rozwoju towarzystw i różnego rodzaju wydawnictw. Pogląd o ścisłej symbiozie pruskiego inteligenta i państwa pojawia się również $\mathrm{w}$ opisywaniu pozycji profesora w pruskim życiu publicznym, kiedy po 1848 roku przestał być politykiem, a stał się „,mędrcem doradzającym władzy" (s. 116).

Rozdział III (Znośna zbędność bytu. Inteligencja polska jako przykład heroizmu $i$ anomalii) poświęcony został kształtowaniu się warstwy inteligenckiej narodu pozbawionego państwa. Zresztą sam Sdvižkov zaznacza, że rozwój inteligencji na gruncie polskim dowodzi, że ona „może istnieć także i bez symbiozy z państwem” 
(s. 125), a nawet można mówić o wspólnych, ponadzaborowych elementach tożsamości polskiej warstwy wykształconej. Autor przytacza dominującą w polskiej literaturze przedmiotu tezę o początkach omawianej warstwy w polskim oświeceniu. W ogóle podkreślenie znaczenia kolejnych epok kulturowych dla rozwoju inteligencji (romantyzmu i pozytywizmu) jest w tym rozdziale silniejsze, niż w przypadku pozostałych wybranych państw. Autor odnosi się również do rodowodu społecznego polskiej warstwy wykształconej, stwierdzając, że polska inteligencja „miała pochodzenie szlacheckie" (s. 150).

W kolejnej części pracy omówiony został przykład rosyjski. Bardzo ciekawie wypada analiza odmiennych niż zachodnioeuropejskie dziejów Rusi od czasów upadku Bizancjum w kontekście kształtowania się elit intelektualnych. W przypadku opisu narodzin rosyjskiej inteligencji interesujące są również rozważania na temat odmienności religijnej państwa carów, odseparowanego chociażby od odrodzeniowego zachwytu nad spuścizną świata antycznego. Sdvižkov, podobnie jak w przypadku polskim, w oświeceniu dostrzega szlachecki „ekwiwalent trzeciego stanu” za panowania Katarzyny II, protoplastę przyszłej inteligencji (s. 176). Na specyfikę rozwoju rosyjskiej warstwy wykształconej miały wpływ między innymi inne tradycje funkcjonowania szkół wyższych, a inteligencja rosyjska, dokonując autodefinicji, podkreślała również kontekst antymieszczański, choć zjawiska inteligenckiego antymaterializmu nie należy zdaniem Autora ograniczać jedynie do Rosji (s. 195). Sdvižkov podkreśla poza tym znaczenie rewolucji 1905-1907 dla rozwoju inteligencji rosyjskiej.

Rozdział piąty, pełniący równocześnie rolę podsumowania, należy uznać za najciekawszy w całej pracy. Zawarto w nim wiele uwag o charakterze metodologicznym, znaczących dla dalszych badań nad poruszonym zagadnieniem. Autor, dokonując bilansu i cech wspólnych i odmiennych rozwoju omówionych przykładów warstw wykształconych, zajmuje się takimi kryteriami badawczymi jak kontury społeczne inteligencji, jej świat wartości, poglądy na kształt porządku społecznego, wzorcowy model państwa, stosunek do religii. Sdvižkov podsumowuje również swe rozważania na temat stosunku inteligencji do innych warstw społecznych i poświęca wiele uwagi kwestiom terminologicznym.

$\mathrm{Z}$ całą pewnością należy docenić umiejętność Autora posługiwania się bogatą terminologią, specyficzną dla każdego z omówionych przykładów. Szanując trud włożony w zapoznanie się z wielojęzycznymi opracowaniami i podkreślając, że Sdvizkov dokonał generalnie słusznego wyboru opracowań, z obowiązku recenzenckiego i z faktu, że została oparta w całości na literaturze przedmiotu, muszę zwrócić uwagę na pominięcie co najmniej kilku istotnych publikacji dla omawianego zagadnienia. Ograniczając te uwagi tylko do „polskiego” rozdziału pragnę stwierdzić, że w moim przekonaniu uwzględnienie niektórych publikacji istotnie 
wzbogaciłby obraz rozwoju polskiej warstwy wykształconej w XIX wieku. Autor nie pominą zupełnie dorobku Tomasza Kizwaltera, nie wykorzystał jednak istotnej dla swych rozważań pracy $O$ nowoczesności narodu. Przypadek polski (Warszawa 1999), ani wcześniejszej monografii tego Autora - Kryzys Oświecenia a początki konserwatyzmu polskiego (Warszawa 1987). Nie uwzględniono twórczości Marcina Króla, na którą składają się chociażby prace poświęcone rozwojowi polskiej myśli konserwatywnej (Konserwatyści a niepodlegtość. Studia nad polska myśla konserwatywna XIX wieku, Warszawa 1985). Ważną pracą dla badacza analizującego dzieje polskiej myśli społecznej i politycznej w Polsce na styku klasycyzmu i romantyzmu pozostaje praca historyka literatury Ryszarda Przybylskiego Klasycyzm czyli prawdziwy koniec Królestwa Polskiego (Gdańsk 1996).

Należy podkreślić bardzo dobrą redakcję wydawniczą polskiego wydania, książkę czyta się dobrze. Tekst został poddany starannej korekcie, a zauważony przeze mnie błąd w podanej dacie śmierci Maurycego Mochnackiego w przypisie 39 na s. 138 (przedstawionego zresztą tamże jedynie jako „krytyka muzycznego i literackiego”) można określić mianem „czeskiego” (podano rok 1843). Praca zawierera indeks osób oraz bibliografię, której zaletą jest podział literatury na poszczególne kraje.

Nie ulega wątpliwości, że Epokę inteligencji należy określić jako książkę udaną i znaczącą dla dalszych badań nad historią nowożytnej europejskiej warstwy wykształconej, jest ona solidną pracą komparatystyczną z zakresu historii społecznej Europy XIX wieku

Tomasz Chrzanowski (Olsztyn) 